\title{
THE COGENERATION FARM
}

Rosa, F.

Veterinary School of Medicine, University of Udine, Via delle Scienze 208, 33100 Udine, Italy

Received: October 10, 2006

Accepted: May 15, 2007

\section{SUMMARY}

The increasing demand for energy, growing scarcity of fossil fuel and environmental concern have stimulated the policy makers in US and Europe to search for alternative sources of energy and the agricultural sector can be a viable solution to this problem. This analysis is addressed to the study of a feasibility of the agro-industrial chain, including farms and industrial plants, to produce biofuel as though it were an "island economy", i.e., a net energy exporter only if the energy and economic values of the biofuel and its co-products exceeds that of all direct and indirect energy inputs. More specifically, the analysis is dedicated to economic, energetic and ecological aspects of the energy cogeneration approach that complete the "Island Model"' and demonstrate to be more sustainable to afford competitively the economic and energetic problems. This model is based on sunflower crop used for production of biodiesel, while the co-product sunflower meal is used in the dairy production, the wastes are recycled in biogas production to generate electricity and heat, and the final residual compost is used for fertilization. This integrated farm energy cogeneration project (IFECO) requires to analyze the different steps of the agro-industrial chain and to afford investments in energy plants and operating costs; to manage the integrated agro-industrial energy chain more skilled labour is required; hence, the convenience to operate IFECO will depend on the capacity to organize and coordinate the many activities performed at different chain steps, with achievement of scale and scope economies. The macroeconomic targets as occupation, value added, import of energy products and inflation, justify the public intervention in programs directed to biodiel defiscalization and support of the energy crops such as soybean, sunflower and others. The results obtained from IFECO suggest that the total energy produced by sunflower chain is significantly superior to the energy spent, the economic gain is reflected in a considerable increase in the annual income and value of land from capitalization of permanent net farm income; finally, the life cycle GHG savings from displacing the fossil fuel (reduction in CO, VOC, PM10, SOx, Nox) are a valuable contribution that ameliorate the ecological conditions of the biosphere and must be considered as a market value if the Kyoto Protocol is to be applied.

\section{Key words: renewable energy, biodiesel, cogeneration, sunflower}

* Corresponding author: Phone at office: 0432-558314; cellular: 320.43.65.951; e-mail rosa@uniud.it 


\section{INTRODUCTION}

The environmental concerns about fossil fuels and energy security have spurred the search for renewable energy and they convinced the policy makers to provide incentives for domestic biofuels production. To be a viable substitute for a fossil fuel, an alternative fuel must have: i) superior environmental benefits over the fossil fuel it displaces, ii) must be economically competitive, iii) must be producible in sufficient quantities to make a meaningful impact on energy demand, and it should also provide a net energy gain over the energy sources used to produce it. According to a study published by Hill et $a{ }^{* *}$ in the Proceedings of the National Academy of Sciences, USA, based on data from farm balance, farm energy and fuel prices, it was demonstrated that the biodiesel from soybeans produces usable energy and reduces greenhouse gases more than the corn-based ethanol, making it more deserving of subsidies. The authors demonstrated the positive balance of energy, the economic competitiveness and the possibility to produce large amounts of biofuel without competing with traditional food markets; specifically, while the ethanol yields $25 \%$ more energy that the energy requested for production, the biodiesel balance is active for more than 93\%. Regarding the emission figures, the biodiesel releases just $1 \%, 8.3 \%$ and $13 \%$ of the agricultural nitrogen, phosphorus and pesticide pollutants, respectively, per net gain energy. Compared with fossil fuels, the greenhouse gas emission is reduced by $12 \%$ with bioethanol and $41 \%$ with biodiesel. The advantages of biodiesel in respect to ethanol are the lower agricultural input (the need for nitrogen fertilizer by soybean is almost zero) and better conversion of feedstock to fuel. The limit of biofuel is the supply: even investing the entire agricultural land to produce soybean and corn, the biofuels supply would satisfy only $12 \%$ of gasoline and $6 \%$ of diesel demand. Transportation biofuel such as synfuel hydrocarbons or cellulose ethanol, if produced from low-input biomass grown on agriculturally marginal land or from waste biomass, could provide much greater supplies and environmental benefits than food-based biofuels.

Many US and EU farmers and their professional associations are presently in favor of the development of green energy markets from agricultural commodities. The USA (see the Clean Air Act Amendments (CAA) of 1990 and the Energy Policy Act of 1992) and EU support the biofuels development by reducing the rate of excise duty for pure or blended fuels. Back in 2003, the EU Commission adopted a biofuels directive setting indicative targets: by 2005, the minimum share of biofuels should be $2 \%$ and it should gradually rise to $5.75 \%$ by the year 2010 (these quantitative commitments have not been applied before 2005 in order to allow enough time for member states to establish the needed production facilities). The mid-term renewable energy targets programmed in the EU require the investment, at the EU level, of $9 \%$ of the agricultural land of which:

** Departments of Ecology, Evolution, and Behavior and Applied Economics, University of Minnesota, St. Paul, MN 55108; and Department of Biology, St. Olaf College, Northfield, MN 55057 
1. for biodiesel - 10 million ha invested in oleaginous plants to produce 14 billion 1 of biodiesel;

2. for ethanol - 5,1 million ha invested in cereals (corn, sorghum) and 0,6 million ha for sugarbeet to produce 13 billions 1 of bioethanol.

\section{Market perspectives}

In 2004, EU biodiesel production used about 4.1 MMT (million t) of rapeseed, or $27 \%$, of a record EU crop of 15.3 MMT. In 2004, the EU harvested oilseeds at an estimated 7.5 million ha of which $60 \%$ was rapeseed, $29 \%$ sunflower seed, and $4 \%$ soybeans. The EU biofuel policy is more favorable to biodiesel production compared with ethanol due to climatic conditions that make the oil production from canola, soybean and sunflower more convenient and due to the higher productivity of biodiesel industrial process.

Prices quoted this year in major representative markets are $20 \%$ higher than the past year; the canola oil quoted at Rotterdam future in May 06 reached 680 \$/t FOB, an increase of $30 \%$ in respect to the past year. This market situation for canola has determined the shift in demand for human consumption of sunflower oil that at current market conditions costs 160 \$/t less than canola oil. According with the estimates of European Biodiesel Board, the EU biodiesel production in 2005 was 3.2 million $t$, an increase of $65 \%$ compared with 1.9 million $t$ produced in 2004; for the year 2006 the production is expected to exceed 6 million $t$ and imports to decline from 850 to 700 thousand t. Major producers are: Germany, with 1.7 million t obtained from canola production ( $+61 \%)$; France, 492 thousand $t$ $(+40 \%)$; Italy, 396 thousand $\mathrm{t}(+24 \%)$; Czech Republic, 133 thousand t; others, 494 thousand t cultivated in France, followed by Hungary and Spain. For this year, an increase of $2.2 \%$ in acreage is expected, corresponding to 2.1 million ha and the production estimated to increase $+7 \%$. Romania and Bulgaria are the main extra UE producers of sunflower.

Table 1: Biofuel production by member states

\begin{tabular}{|c|c|c|c|c|c|c|c|c|c|}
\hline \multirow{2}{*}{ Country } & \multicolumn{3}{|c|}{ Biodiesel } & \multicolumn{3}{|c|}{ Ethanol } & \multicolumn{3}{|c|}{ Total } \\
\hline & 2002 & 2003 & 2004 & 2002 & 2003 & 2004 & 2002 & 2003 & 2004 \\
\hline Germany & 534 & 848 & 1226 & 0 & 0 & 26 & 534 & 848 & 1252 \\
\hline France & 432 & 424 & 413 & 114 & 102 & 129 & 546 & 526 & 542 \\
\hline Italy & 250 & 322 & 379 & 0 & 0 & 0 & 250 & 322 & 379 \\
\hline Spain & 0 & 8 & 15 & 223 & 201 & 246 & 223 & 209 & 261 \\
\hline Denmark & 11 & 49 & 83 & 0 & 0 & 0 & 11 & 49 & 83 \\
\hline Czech Republic & 83 & 83 & 72 & 8 & 0 & 0 & 91 & 83 & 72 \\
\hline Austria & 30 & 38 & 68 & 0 & 0 & 0 & 30 & 38 & 68 \\
\hline Sweden & 0 & 0 & 0 & 64 & 64 & 64 & 64 & 64 & 64 \\
\hline The Netherlands & 0 & 0 & 0 & 83 & 76 & 45 & 83 & 76 & 45 \\
\hline United Kingdom & 4 & 11 & 11 & 0 & 0 & 0 & 4 & 11 & 11 \\
\hline Slovak Republic & 0 & 0 & 19 & 0 & 0 & 0 & 0 & 0 & 19 \\
\hline Lithuania & 0 & 0 & 8 & 0 & 0 & 0 & 0 & 0 & 8 \\
\hline Intervention stock & 0 & 0 & 0 & 0 & 87 & 110 & 0 & 87 & 110 \\
\hline Total & 1344 & 1783 & 2294 & 492 & 530 & 620 & 1836 & 2313 & 2914 \\
\hline
\end{tabular}

Source: Eurobserver no. 167, May June 05 
While the oil yield per ha obtained from different oilseed commodities fluctuates in a wide range between countries and regions, the basic productivity of the palm oil is a significant economic feature with a yield of about of $4 \mathrm{t} / \mathrm{ha}$. In Europe, the rapeseed (assuming a 40\% oil content and a gross yield of 3 t/ha) has an oil yield of about $2 \mathrm{t}$ /ha and the sunflower seed (assuming a $45 \%$ oil content and a gross yield of $2.4 \mathrm{t} / \mathrm{ha}$ ) has an oil yield of $1.08 \mathrm{t} / \mathrm{ha}$ while the high oleic variety has a yield of $1.2 \mathrm{t} /$ ha almost the same as rapeseed under optimal conditions. To put in another way, one ha of oil palm can meet the vegetable oil needs of 133 people compared with 40 people from one ha of rapeseed and 19 people from one ha of "traditional" sunflowers (assuming $30 \mathrm{~kg}$ per head annual seed oil consumption in the European countries). Actually, the economic role of sunflower production is more complicated, notably by ecology and joint production factors.

The USDA Outlook for the oil commodity production 2006/07 made in June 2006 confirmed the growth of canola (Brassica napus) to 4.88 million ha in the 25 EU countries. Also the soybean investments were growing at a rate of $12 \%$ from 273 to 305 thousand ha while the expected production was estimated to reach 943 thousand $t$. Sunflower acreage increased by 2.2 but the production increased by $7.4 \%$.

Table 2: Outlook for the oil seed in the EU-25

\begin{tabular}{|c|c|c|c|c|c|c|c|}
\hline Commodity & $2005 / 06$ & $2006 / 07$ & $\%$ Change & Commodity & $2005 / 06$ & $2006 / 07$ & $\%$ Change \\
\hline \multicolumn{4}{|c|}{ Investment in 000 ha: absolute values } & \multicolumn{4}{|c|}{ Investment in 000 ha: \%values } \\
\hline Soybean & 0,273 & 0,305 & 11.72 & Soybean & 3,87 & 4,21 & 8.78 \\
\hline Canola & 4,762 & 4,876 & 2.39 & Canola & 67,53 & 67,32 & -0.31 \\
\hline Sunflower & 2,017 & 2,062 & 2.23 & Sunflower & 28,60 & 28,47 & -0.46 \\
\hline Total & 7,052 & 7,243 & 2.71 & Total & 100.00 & 100,00 & 0.00 \\
\hline \multicolumn{4}{|c|}{ Production in $000 \mathrm{t}$ : absolute values } & \multicolumn{4}{|c|}{ Production in $000 \mathrm{t}:$ \% values } \\
\hline Soybean & 0,874 & 943 & 7.89 & Soybean & 4.37 & 4.69 & 7.42 \\
\hline Canola & 15,417 & 15161 & -1.66 & Canola & 77.03 & 75.41 & -2.10 \\
\hline Sunflower & 37,24 & 4000 & 7.41 & Sunflower & 18.61 & $19 ., 90$ & 6.94 \\
\hline Total & 20,015 & 20104 & 0.44 & Total & 100.00 & 100.00 & 0.00 \\
\hline
\end{tabular}

Source: our elaboration on USDA data

Table 3: Production in t per ha and energy conversion of major oil crops

\begin{tabular}{lccccccc}
\hline Product & $\mathrm{t} / \mathrm{ha}$ & $\begin{array}{c}\text { Conversion } \\
\text { ratio }\end{array}$ & Biodiesel*,t Energy, MJ** & Co-products, $\mathrm{t}$ & Energy, MJ & Total \\
\hline Canola & 3.0 & $30-38 \%$ & 1.08 & 39,420 & $\begin{array}{c}\text { Glycerine }(0.09) \\
\text { Meal }(1.02)\end{array}$ & $\begin{array}{c}1,575 \\
15,300\end{array}$ & 56,295 \\
Sunflower & 2,5 & $45 \%$ & 1.25 & 40,150 & $\begin{array}{c}\text { Glycerine }(0.11) \\
\text { Meal }(1.25)\end{array}$ & $\begin{array}{c}1,925 \\
21,000\end{array}$ & 63,075 \\
Soybean & 3,4 & $20 \%$ & 0.7 & 25,550 & $\begin{array}{c}\text { Glycerine }(0.13) \\
\text { Meal }(2.00)\end{array}$ & $\begin{array}{c}2,275 \\
30,000\end{array}$ & 57,825 \\
\hline
\end{tabular}

* Biodiesel production is obtained from the transesterification reaction

** the following energy conversion index in MJ/t were used: biodiesel: 36.500; meal: 15.000; glycerine: 17.500 .

Source: our elaboration from different sources of data. 
Table 3 reports the data about the average yield per ha and the corresponding energy production of the most widely cultivated oleaginous commodities in Europe.

\section{Oil prices of biofuel commodities}

The valuation of the oil component of most oilseeds is subject to a varying degree of pricing pressure from the main alternative source of vegetable oils. The major share of receipts from rapeseed and sunflower production is from the oil component and prices which usually follow that of palm oil working as a leading indicator of the oil market; though in the EU sunflower seed oil usually has premium over soybean or palm oil. Price trends suggest the following considerations: prices of different commodities grow over time and fluctuate quite closely as suggested by Pearson correlation coefficients and by the RMSE computed on the margins. The price-time series seems to be cointegrated and the prices follow the leading indicator, palm oil price driving the other prices. This situation makes easier to predict the evolution of bio-fuel markets in the coming years and the experts have statistical instruments to suggest to the farmers the best decisions to optimize the cultivation.

Table 4: Price (cent/pound) of US vegetable oil and fats

\begin{tabular}{|c|c|c|c|c|c|c|c|c|c|c|c|}
\hline \multirow[b]{2}{*}{ Year (b) } & \multicolumn{11}{|c|}{ Oil price of different biofuel commodities (a) } \\
\hline & 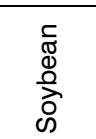 & 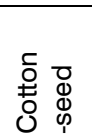 & 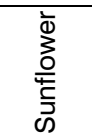 & 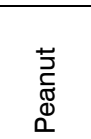 & 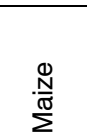 & $\frac{\mathscr{D}}{\stackrel{\mathscr{O}}{\simeq}}$ & 읽 & i⿱宀 & $\begin{array}{l}\text { ల్ } \\
\stackrel{\mathbb{\Phi}}{\Sigma}\end{array}$ & S.D & C.V \\
\hline $94 / 95$ & 27,51 & 29,23 & 28,1 & 28,9 & 26,47 & 28,55 & $\mathrm{~N} / \mathrm{A}$ & $\mathrm{N} / \mathrm{A}$ & 28,13 & 1,01 & 0,04 \\
\hline $95 / 96$ & 24,7 & 26,53 & 25,42 & 40,3 & 25,24 & 29,05 & 21,7 & 21,56 & 26,81 & 5,97 & 0,22 \\
\hline $96 / 97$ & 22,51 & 25,58 & 22,58 & 43,7 & 24,05 & 25,68 & 23,02 & 23,01 & 26,27 & 7,16 & 0,27 \\
\hline $97 / 98$ & 25,83 & 28,85 & 27 & 49 & 28,94 & 28,83 & 19,46 & 20,69 & 28,58 & 9,05 & 0,32 \\
\hline $98 / 99$ & 19,8 & 27,32 & 20,15 & 39,74 & 25,3 & 22,48 & 14,66 & 15,14 & 23,07 & 8,05 & 0,35 \\
\hline $99 / 00$ & 15,59 & 21,56 & 16,68 & 35,39 & 17,81 & 17,1 & 13,64 & 13,21 & 18,87 & 7,16 & 0,38 \\
\hline $00 / 01$ & 14,15 & 15,98 & 15,88 & 34,81 & 13,54 & 17,56 & 14,61 & 13,43 & 17,50 & 7,14 & 0,41 \\
\hline $01 / 02$ & 16,46 & 17,98 & 23,25 & 32,52 & 19,14 & 23,45 & 13,55 & 13,87 & 20,03 & 6,28 & 0,31 \\
\hline $02 / 03$ & 22,04 & 37,75 & 33,11 & 46,7 & 28,17 & 29,75 & 18,13 & 17,8 & 29,18 & 10,00 & 0,34 \\
\hline $03 / 04$ & 28,76 & 32,8 & 32,07 & 63,59 & 28,14 & 0 & 26,4 & 27,07 & 29,85 & 17,18 & 0,58 \\
\hline
\end{tabular}

a Source: Ash et al. (2003).

$\mathrm{b}$ The year is beginning in October.

\section{The integrated farm energy cogeneration project (IFECO)}

Economic, ecologic and energy balances validate the farm strategy to produce renewable energy with the cogeneration approach defined an energy-efficient and environmentally-friendly method of producing at the same time different forms of energies likely: fuel, electricity (power), steam and/or heath in one process. With only one fuel it can be reached a system efficiency exceeding the $60 \%$. Fuels used in 
cogeneration include natural gas, fuel oil, propane, bio-mass, bio-waste, and renewable energies such as wood or wood waste. The purpose of this application is to demonstrate that the integrated farm cogenerative energy approach (IFECO) will contribute to a significant improvement in the economic and energy balance by integrating physical, chemical, biochemical and physiological processes (trans-esterification, photosynthesis, ruminant metabolism and microbiological digestion) to produce alternative energies from products generated by agricultural activities performed in a unique farm: oil, biofuel, meal, dairy products, biogas (heat and electricity), composts, marketable in different market outlets. This farm, integrated in the Agro-Industrial chain, will be able to increase farm incomes and the energy balance and will mitigate the greenhouse effect (GHG). This approach may require the collaboration between the government, industry and farmers to optimize the value of energy production and it is justified by domestic and international advantages: i) expected macro economic targets given by the contribution of agriculture to GNP and occupation, new jobs created along the agro-industrial chain, reduction in commercial deficit balance due to fossil oil imports, and creation of marketable intangible goods represented by the clean environment; ii) microeconomic targets represented by increase in farm incomes, more market opportunities for farm commodities, increase in land market value; iii) at international level, new market opportunities are opened for the new countries such as Romania, Bulgaria, Slovakia, Serbia having great agricultural potentials.

The integrated farm energy cogeneration project (IFECO) focalizes the different farm integrated activities that make easier and less costly to transform the farm products into alternate forms of energies. The project includes:

1. the agro-industrial oil chain with: a) sunflower cultivation of high oleic varieties; b) industrial plant for mechanical extraction with crushing and chemical extraction with hexane; c) the oil conversion in biodiesel. ${ }^{* * *}$ Two coproducts are obtained with biodiesel production: high-protein meal used as animal feed and glycerine used in the cosmetic industry.

2. the dairy enterprise, to use the sunflower meal to feed cows;

3. the biogas plant, to recycle the liquid and solid wastes obtained from the dairy activity, used: 1 ) to produce heat of which a quota is recycled in the farm and the rest is distributed to local communities; 2) to produce electricity to be sold to the general contractor. The organic residual of biogas fermentation is used as organic fertilizer. For this project, the cogeneration requires the sunflower cultivation that in Italy matches with local agronomic and climatic conditions. The following conditions are required:

- a minimum acreage dedicated to the cultivation of energy crops, sufficient to exploit the scale economies;

*** Experiences in Germany demonstrate that the canola oil can be used directly in endothermic combustion engines 
- the constitution of a farm network to feed the industrial plants with a minimum efficient size to achieve scale economies;

- the participation of farmers in biofuel chain decisions and profit distribution;

- easy connection with the electric network and clear rules for energy payment (agreement with GRTE);

- agreements with local communities for heating distribution and facilities;

- participation of the government institution in the cogeneration farm project.

\section{Life Cycle Environmental Effects}

Biofuel production implies a negative environmental impact through movement of agrichemicals, especially nitrogen $(\mathrm{N})$, phosphorus $(\mathrm{P})$, and pesticides, from farms to other habitats and aquifers. Agricultural N and P are transported by leaching and surface flow to surface, ground water, and coastal waters causing eutrophication, loss of biodiversity, and elevated nitrate and nitrite in drinking-water wells. Pesticides can move by similar processes. Data on agrichemical inputs for corn and soybeans and on efficiencies of net energy production from each feedstock reveal, after partitioning these inputs between the energy product and co-products, that biodiesel uses, per unit of energy gained, only $1.0 \%$ of the N, $8.3 \%$ of the P, and $13 \%$ of the pesticide (by weight) used for corn grain ethanol. Low levels of biodiesel blended into fossil diesel reduce emissions of VOC, CO, PM10, and $\mathrm{SO}_{\mathrm{x}}$ during combustion, and biodiesel blends show reduced life-cycle emissions for three of these pollutants (CO, PM10, and $\mathrm{SO}_{\mathrm{x}}$ ) relative to fossil diesel.

\section{The sunflower oil chain: energy input and cost}

To represent the sunflower chain, ha was taken as the reference unit measure for the computations. The sunflowers numbers are: 2,5/50/45; this means that, in normal conditions, one ha of high oleic sunflower renders $2.5 \mathrm{t}$ of seed and assuming the $50 \%$ of oil rent and a $95 \%$ of oleic acid from mechanical extraction the total amount of oleic acid produced from one ha of sunflower is $2.5 \times 0.50 \times 0.95=1.1875$ $\mathrm{t}$, and the meal is $1.313 \mathrm{t}$. The chemical extraction with hexane will produce additional $5 \%$ of oil equivalent to $1.313 \mathrm{t} \times 0.05=65.65 \mathrm{~kg}$; hence the total oil produced is $1.253 \mathrm{t}(50.12 \%)$, the integral meal is $1.247 \mathrm{t}(49.88 \%)$ and the final sum is still $2.5 \mathrm{t}$. Without making a large error it can be assumed that $50 \%$ of the seed weight is oil $^{* * * *}$ and the other $50 \%$ is integral meal. If the tegument is taken away from the integral meal, the composition will be the: Oil $=1.253 \mathrm{t}(50.12 \%)$ corresponding to 1.424 liters (see the density coefficient); cleaned meal=1.105 t. (44.20\%); teguments $=0.142(5.68 \%)$.

**** The oil weight is transformed in liter by using the density coefficient 1.145 . 
The trans-esterification reaction requires oil and methyl alcohol to produce bioester and glycerin in the following proportions: $1 \mathrm{t}$ oil $+0.1 \mathrm{t}$ methyl alcohol+catalyst $=1 \mathrm{t}$ biodiesel $+0.1 \mathrm{t}$ glycerin. For one ha invested in sunflower we obtain 1.253 $t$ biodiesel that has an energetic conversion ratio equal to 1:3.2 (US Ministry for Energy) meaning that for each unit of fossil fuel consumed 3.2 units of energy are obtained; considering the entire consumption of energy the ratio will be reduced to $1: 1.9$. The conversion efficiency ratio will depend on genetics, photosynthesis, agronomic and climatic conditions.

Table 5: Sunflower energy inputs * and costs per ha

\begin{tabular}{|c|c|c|c|c|c|c|c|c|}
\hline Item & Unit & Quantity & Kcal/unit & $\begin{array}{c}\text { Kcal } \\
\times 1000 \\
\end{array}$ & Mj/ha & $\mathrm{MJ} / \mathrm{liter}$ & $\begin{array}{l}\text { Cost } \\
\$ / \text { ha }\end{array}$ & $\begin{array}{c}\text { Cost } \\
\text { Euro/ha }\end{array}$ \\
\hline \multicolumn{9}{|l|}{ Production stage } \\
\hline \multicolumn{2}{|c|}{ Farm household energy use hour (a) } & 8.6 & 40.000 & 344 & 1.44 & 0.05 & 111.80 & 86.00 \\
\hline Machinery production & $\mathrm{Kg}(\mathrm{b})$ & 15 & 24.000 & 360 & 1.51 & 0.04 & 95.00 & 63.05 \\
\hline Farm fossil fuel & liter (c) & 180 & 10.000 & 1800 & 7.54 & 0.22 & 93.62 & 82.00 \\
\hline Nitrogen & $\mathrm{Kg}$ & 60 & 17.600 & 1056 & 4.42 & 0.13 & 35.00 & 26.92 \\
\hline Phosphorus & $\mathrm{Kg}$ & 30 & 4.113 & 123 & 0.52 & 0.02 & 19 & 14.77 \\
\hline Potassium & $\mathrm{Kg}$ & 34 & 3.176 & 108 & 0.45 & 0.01 & 11.33 & 8.72 \\
\hline Lime & $1000 \mathrm{Kg}$ & 0 & 0.000 & 0 & 0.00 & 0.00 & 0.00 & 0.00 \\
\hline Seed & unit (d) & $1=5 \mathrm{~kg}$ & & 450 & 1.88 & 0.06 & 27.00 & 20.77 \\
\hline Herbicide/pesticide & $\mathrm{Kg}$ & 3 & 100.000 & 300 & 1.26 & 0.04 & 45.00 & 34.62 \\
\hline Electricity & Kwh & 10 & 2.900 & 29 & 0.12 & 0.00 & 1.10 & 0.85 \\
\hline Crop and biofuel transport & $\mathrm{Kg}$ & 675 & 0.252 & 170 & 0.71 & 0.03 & 81.00 & 62.31 \\
\hline Total production stage & & & & 4740.38 & 19.85 & 0.60 & 520.05 & 400.00 \\
\hline Sunflower yield $=2.5 \mathrm{t} / \mathrm{ha}$ & $\mathrm{Kg}$ & 2500 & 2.000 & 5000.00 & & & & \\
\hline kcal output/input & & & & 1.05 & & & & \\
\hline \multicolumn{9}{|l|}{ Processing stage } \\
\hline Sunflower & $\mathrm{Kg}$ & 2500 & & 16000 & & 0.221 & 450.00 & 346.15 \\
\hline Electricity & Kwh & 270 & & 700 & & 0.010 & 19.00 & 14.62 \\
\hline Steam & Kcal & 1350000 & & 1350 & & 0.019 & 11.00 & 8.46 \\
\hline Cleanup water & Kcal & 160000 & & 160 & & 0.002 & 1.30 & 1.00 \\
\hline Space heat & Kcal & 152000 & & 152 & & 0.002 & 1.25 & 0.96 \\
\hline Direct heat & Kcal & 440000 & & 440 & & 0.006 & 3.60 & 2.77 \\
\hline Losses & Kcal & 440000 & & 300 & & 0.004 & 2.50 & 1.92 \\
\hline Stainless steel & $\mathrm{Kg}$ & 300000 & & 160 & & 0.002 & 18.70 & 14.38 \\
\hline Steel & $\mathrm{Kg}$ & 11 & & 250 & & 0.003 & 18.00 & 13.85 \\
\hline Cement & $\mathrm{Kg}$ & 20 & & 100 & & 0.001 & 19.00 & 14.62 \\
\hline Total processing stage & & & & 19612 & & 0.271 & 544.35 & 418.73 \\
\hline
\end{tabular}

(a) assuming a person works $1800 \mathrm{~h} /$ year, utilizes an average of 8 thosand liters of oil equivalent and labor paid $\$ 13 / \mathrm{h}$ or 10 Euro/h

(b) Pimentel data, 1996; machinery is rorated per ha and 10 year life cycle;

(c) caloric power is 10 thousand $\mathrm{Kcal} / \mathrm{I}$

(d) assuming 10 thousand $\mathrm{kcal} / \mathrm{kg}$ 
Table 6: Energy balance

\begin{tabular}{llll}
\hline Product & Input & Output & Rent \\
\hline Biodiesel & 0,27 & 1,00 & 3,70 \\
Meal and Glycerine & 0,60 & 0,66 & 1,10 \\
Total & 0,87 & 1,66 & 1,91 \\
\hline
\end{tabular}

\section{Sunflower meal and the cattle diet}

Sunflower meal is used in cattle diet to provide the daily quantity of protein to satisfy the daily nutritional intake of a cattle in lactation; a current diet includes 20 $\mathrm{kg}$ of fiber of which, $3.5 \mathrm{~kg}$ (17\%) must be represented by protein intake, hence the annual consumption is estimated at $7.3 \mathrm{t}$ of total fiber and $1.2 \mathrm{t}$ of protein. Assuming a daily consumption of $1.5 \mathrm{~kg}$ of integral sunflower meal (3/7 of the protein fraction) and $2 \mathrm{~kg}$ of pure sunflower meal (4/7 of the protein fraction) the protein requirement for one year is $0.50+0.65=1.15 \mathrm{t}$; for this it is required to have 1.025 $\mathrm{t}$ of sunflower seed (41\%) to produce the integral meal and 1,475 t (59\%) to produce the pure meal. The suggested ratio between integral floor and pure meal is approximately 0.75 .

The $\mathrm{UF}^{* * * * *}$ requested by cattle in lactation is $820 \mathrm{UF} / \mathrm{t}$ of dried matter that is supplied with:

- Integral meal: $0.5 \mathrm{t} \times 820=410 \mathrm{UF}=5437.5 \mathrm{MJ}$;

- Pure meal: $0.65 \mathrm{t} \times 820=533 \mathrm{UF}=7115.5 \mathrm{MJ}$.

The caloric intake is measured with the relation: $1 \mathrm{UF}=2100 \mathrm{Kcal}$; it can be estimated the annual consumption of calories for a cow equivalent to $10 \times 10^{6}$ : or 10 megacalories; the milk has a caloric value of $65 \mathrm{kcal} / \mathrm{liter}$, the annual production is 10,000 liters equivalent to 650 thousand and calories or 0.6 megacalories the ratio between production and consumption is $1: 10$.

From the waste produced in one year by a head of cattle weighting around 600 $\mathrm{kg}$ it can be obtained $304 \mathrm{~m}^{3}$ biogas.

Table 7: Values of biogas and energy

\begin{tabular}{|c|c|c|c|c|c|c|c|c|}
\hline $\begin{array}{l}\text { Animal } \\
\text { waste }\end{array}$ & $\begin{array}{c}\text { Average } \\
\text { production } \\
\left(\mathrm{m}^{3} / \mathrm{kg} \mathrm{L.W.}\right)^{*}\end{array}$ & $\begin{array}{c}\text { Total pro- } \\
\text { duction } \\
\left(\mathrm{m}^{3}\right)\end{array}$ & $\begin{array}{l}\text { Total pro- } \\
\text { duction } \\
\text { (t) }\end{array}$ & $\begin{array}{c}\text { Biogas } \\
\left(\mathrm{m}^{3}\right)\end{array}$ & $\begin{array}{c}\text { Electric } \\
\text { energy } \\
(\mathrm{kwh})\end{array}$ & $\begin{array}{c}\text { Total } \\
\text { Electric } \\
\text { energy** }\end{array}$ & $\begin{array}{l}\text { Thermal } \\
\text { energy } \\
\text { (kwh) }\end{array}$ & $\begin{array}{c}\text { Total } \\
\text { thermal } \\
\text { energy ** }\end{array}$ \\
\hline Liquid waste & 0.023 & 13.80 & 13.80 & 207 & 372.60 & \multirow{2}{*}{$\begin{array}{c}545.50 \mathrm{kwh} \\
(1,964 \mathrm{MJ})\end{array}$} & 745.20 & \multirow{2}{*}{$\begin{array}{l}1.091 \mathrm{kwh} \\
(3,928 \mathrm{MJ})\end{array}$} \\
\hline Solid waste & 0.016 & 9.60 & 2.88 & 97 & 172.90 & & $345, .70$ & \\
\hline \multicolumn{9}{|c|}{$\begin{array}{l}\text { *conversion coefficient by ERSAL (Ente Regionale di Sviluppo Agricolo della Lombardia) for the } \\
\text { computation of the average annual production of animal waste http://www.aquanetpc.it/download/ } \\
\text { files/cd_01/7_modelli_IPNOA.pdf) } \\
\star \star 1 \mathrm{kWh}=3,6 \mathrm{MJ}\end{array}$} \\
\hline
\end{tabular}

$* * * * * \mathrm{UF}$ is the unit measure of the caloric power of a ruminant diet. 
Table 8: IFECO Energy production

\begin{tabular}{lccccc}
\hline Item & Unit & $1 \mathrm{Ha}$ & $10 \mathrm{Ha}$ & $100 \mathrm{Ha}$ & $1000 \mathrm{Ha}$ \\
\hline Sunflower seed production & $\mathrm{t}$ & 2.50 & 25 & 250 & 2500 \\
Oil production (extraction with crushing and hexane) & $\mathrm{t}$ & 1.25 & 12.5 & 125 & 1250 \\
Meal production & $\mathrm{t}$ & 1.25 & 12.5 & 125 & 1250 \\
Cows $(\mathrm{nc})$ & Number & 2 & 20 & 200 & 2000 \\
Electric power generator $\mathrm{eg}=\mathrm{kw} / \mathrm{cow})$ & $\mathrm{Kw}$ & 0.6 & 0.66 & 0.72 & 0.80 \\
Working time per year=h/day $\times \mathrm{gg})$ & $\mathrm{Hour}$ & 5000 & 6000 & 6500 & 7200 \\
Electric energy produced per year $(\mathrm{nc} \times \mathrm{eg} \times \mathrm{h} \times 0.3)$ & $\mathrm{MWh}$ & 1.8 & 23.8 & 280.8 & 3456.0 \\
Termic energy produced per year & $\mathrm{MWh}$ & 1.64 & 21.66 & 255.5 & 3145 \\
\hline
\end{tabular}

Table 9: Farm Production per ha and per year

\begin{tabular}{lcc}
\hline & Unit of measure & Production \\
\hline 1) Sunflower seed cultivation & $\mathrm{t}$ & 2.5 \\
Of which: & $\mathrm{t}$ & \\
Seeds for integral meal & $\mathrm{t}$ & 1.025 \\
Seeds for clean meal & $\mathrm{t}$ & 1.475 \\
Integral meal & $\mathrm{t}$ & 0.600 \\
Clean meal & $\mathrm{t}$ & 0.650 \\
Total meal & $\mathrm{Unit}$ & 1.250 \\
\hline 2) Dairy activity & $\mathrm{t}$ & 1 \\
Production of milk (two cows) & $\mathrm{unit}$ & 20 \\
Production of meat (two calves) & & 2 \\
\hline 3) Biogas production & $\mathrm{m}^{3}$ & 13.80 \\
Production of slurry & $\mathrm{m}$ & 9.60 \\
Production of manure & $\mathrm{m}$ & 0.304 \\
Total production of biogas & $\mathrm{Number}$ & 2 \\
Cows (nc) & $\mathrm{Kw}$ & 0.6 \\
Electric power generator eg $=\mathrm{kw} / \mathrm{cow})$ & $\mathrm{Hour}$ & 5000 \\
Working time per year $=\mathrm{h} / \mathrm{day} \times \mathrm{gg})$ & $\mathrm{MWh}$ & 1.8 \\
Electric energy produced per year $(\mathrm{nc} \times \mathrm{eg} \times \mathrm{h} \times 0.3)$ & $\mathrm{MWh}$ & 1.64 \\
Thermal energy produced per year &
\end{tabular}


Finally we present the total energy production per ha and per year of the biodiesel chain.

Table 10: The energy produced from the sunflower chain per ha and per year

\begin{tabular}{|c|c|c|}
\hline \multicolumn{3}{|c|}{ Energy produced per $\mathrm{Ha}$ and per year } \\
\hline Item & Kcal $\times 1000$ & MJ \\
\hline Biodiesel (1) & 10,000 & 41.87 \\
\hline Sunflower meal (2) & 1,760 & 7.12 \\
\hline Electricity from biogas & 1,548 & 6.48 \\
\hline Thermal energy from biogas & 1,410 & 5.90 \\
\hline Milk: 2 cows producing 20 t milk (3) & 1,300 & 5.44 \\
\hline Total & 16,018 & 66.82 \\
\hline \multicolumn{3}{|c|}{$\begin{array}{l}\text { (1) } 1000 \mathrm{Kg} \text { of biodiesel has an energy equivalent of } 9 \text { million kcal; assuming the production per ha } \\
\text { of } 1.20 \mathrm{t} \text { the total energy is } 1.20 \times 9 \times 10^{3}=10 \text { million kcal; } \\
\text { (2) The sunflower meal contains } 600 \mathrm{UF} / \mathrm{t} \text { and the energy of } 1 \mathrm{UF} \text { corresponding to } 2100 \mathrm{kcal} \text {; then } \\
\text { the energy value is } 2100 \times 600 \times 1.4=600 \mathrm{UF} / \mathrm{t} \\
1 \mathrm{Kcal}=4.18 \mathrm{~J} ; 1 \mathrm{Kwh}=860 \mathrm{Kcal}=3.6 \mathrm{MJ}=3.6 \times 10^{6} \mathrm{~J} \text {; see: http://www. unit-conversion.info/energy.html } \\
\text { (3) The energy contained in the milk is } 65 \mathrm{kcal} / \text { liter'; hence the total energy per ha is } 20000 \times 65=1.3 \\
\text { million calories }\end{array}$} \\
\hline
\end{tabular}

\section{Economics of biogas production}

For the economic analysis, some assumption must be made about the investment and operational costs involved in biogas production. These costs change depending on technologies used, $\mathrm{K} / \mathrm{L}$ ratio and plant size, management organization, contractual relations and others. While the estimates about biodiesel production are sufficiently supported by empirical data, the biogas production and use are relatively recent: the fermentation efficiency depends on the substrate composition and control of environmental conditions. Slurry and manure are the final products of the animal metabolism; eventually mixed with other organic materials, like corn, grass, lard and others these are fermented in an anaerobic process (microbial digestion) to produce biogas. The amount of waste produced varies with the type of animal, but on the average it ranges between 60 and $85 \mathrm{~kg}$ (wet basis) per 1,000 kg live animal mass per day in intensive production systems. The energy potential of these wastes is given by the volatile solids (organic matter) content, which ranges from 10 to $18 \%$ of the total wet waste or 75 to $85 \%$ of the dry weight (ASAE, 1997). The energy potential of the manure produced was evaluated using the following formula: $12 \times 1012$ to $25 \times 1012 \mathrm{Btu}$ annually depending on the method used for conversion (Parker et al., 1997). This equates to 12 to 25 billion cubic feet of natural gas annually. The esothermic reaction is described as follows:

$\mathrm{CH}_{4}+2 \mathrm{O}_{2} \rightarrow \mathrm{CO}_{2}+2 \mathrm{H}_{2} \mathrm{O}+886 \mathrm{KJ}(212 \mathrm{Kcal})$

The caloric power varies between $18.81 \mathrm{MJ} / \mathrm{m}^{3}\left(4,500 \mathrm{kcal} / \mathrm{m}^{3}\right)$ and $27.17 \mathrm{MJ} /$ $\mathrm{m}^{3}\left(6,500 \mathrm{kcal} / \mathrm{m}^{3}\right)$ (Bandieramonte et al., 1998).

Here follow the results of a biogas production plant.

Biogas production: technical evaluation

Category: Cows

No. of heads: 1000

Average live weight per head: 650 
Table 11.1: Sludge production of the herd

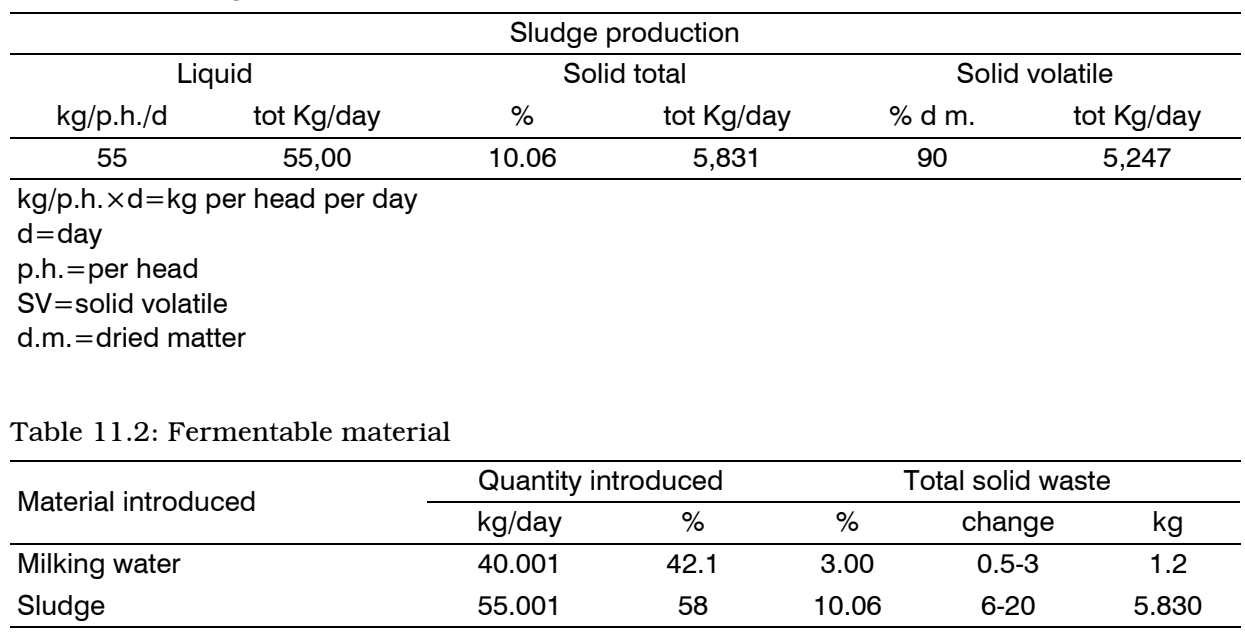

Table 11.3: Biogas and methane production

\begin{tabular}{ccccccccc}
\hline \multicolumn{3}{c}{ Solid volatile } & \multicolumn{3}{c}{ Biogas production } & \multicolumn{3}{c}{ Methane production } \\
\hline$\%$ d.m. & Range & $\mathrm{Kg}$ & $\mathrm{mc} / \mathrm{kg} \mathrm{SV}$ & Range & $\mathrm{mc} /$ day & $\%$ & $\mathrm{mc} /$ day & $\begin{array}{c}\text { Total } \\
\mathrm{mc} / \text { year }\end{array}$ \\
\hline 85 & $65-90$ & 1.02 & 0.35 & $0.32-0.36$ & 357 & 58 & 207 & 75,555 \\
90 & $65-90$ & 5.247 & 0.35 & $0.32-0.36$ & 1,835 & 58 & 1065 & 388,725 \\
\hline
\end{tabular}

Table 11.4: Energy production

\begin{tabular}{lcc}
\hline Generator efficiency & $\%$ & 38 \\
Thermal energy used & $\%$ & 40 \\
Thermal energy dissipated & $\%$ & 10 \\
Thermal energy used & $\%$ & 10 \\
Thermal energy dissipated & $\%$ & 1 \\
in use & hour/day & 24 \\
in use & day/year & 340 \\
in use & hour/year & 8.16 \\
\hline
\end{tabular}

Table 11.5: Energy production

\begin{tabular}{|c|c|c|c|c|c|c|c|}
\hline \multicolumn{4}{|c|}{ Electricity } & \multicolumn{4}{|c|}{ Heating } \\
\hline \multicolumn{2}{|c|}{ Power } & \multicolumn{2}{|c|}{ Energy } & \multicolumn{2}{|c|}{ Power } & \multicolumn{2}{|c|}{ Energy } \\
\hline Gross & Net & Day & Year & Gross & Net & Day & Year \\
\hline kw e & kw e & kwh e & kwh e & $\mathrm{Kw}$ th & kw th & kw th & $k w$ th \\
\hline 190 & 169 & 4,062 & 1,381 & 310,300 & 155,200 & 3,724 & 1,266 \\
\hline
\end{tabular}

The energy market in Italy is regulated by law: presently the value of Green Certificate (GC) is determined by the Legislative Decree no 79/99, (hereinafter named 
the "Bersani Decree"), that obliges all energy users or producers to insert, since the year 2002, in the national electric network at least $2 \%$ of the total amount of energy used in previous year in form of renewable energy. To obtain this result, interested operators are required to file the GC with the Administrator of the National Circuits Network (hereinafter "the Administrator"). A new law 239/2004 (Marzano Law) reduced the amount of "Green Certificate", to $50 \mathrm{MWh}$ previously fixed to $100 \mathrm{MWh}$. The price of GC for 2004 was approximately 10 Eurocent/KWh and is currently increasing.

Table 12: Economic balance of biogas production for 1000 cows

\begin{tabular}{|c|c|c|c|c|}
\hline Income & Unit value Euro/Kwh & Kwh & Total value & Note \\
\hline Green Certificate & 0,10892 & 1.80 & 0.196 & average \\
\hline Self-consumption & & & 1.8 & average \\
\hline Electric energy sold & 0,08 & 1.80 & 0.144 & AEEG 34/05 \\
\hline Electric energy purchased & & 0 & 0 & average \\
\hline Thermal energy sold & 0 & 1.64 & 0 & average \\
\hline Total income & & & 265,030 & year \\
\hline Costs per head & Euro /day & & & \\
\hline Maintenance & 75.34 & & 24,862 & average \\
\hline Biomass & 0 & & 0 & average \\
\hline Industrial water & 0 & & 0 & average \\
\hline Labor & 0 & & 0 & average \\
\hline Other & & & 0 & average \\
\hline Total costs & & & 24,862 & year \\
\hline \multicolumn{5}{|l|}{ Net cash flow } \\
\hline Total income & & & 265,030 & year \\
\hline Total costs & & & 24,862 & year \\
\hline net cash flow & & & 240,167 & year \\
\hline \multicolumn{5}{|l|}{ Investment } \\
\hline Total & & & 684,681 & \\
\hline State contribution & & & 0.000 & \\
\hline Net investment & & & 684,681 & \\
\hline PBP (Pay back period) & & & 2.9 & year \\
\hline
\end{tabular}

\section{Evaluation of the sunflower biodiesel chain in Italy}

The economic analysis is the balance of the different steps of the sunflower chain. The cost analysis is a full costing using the "activity-based costing" scheme that allows to obtain the information about the costs of activities performed by the plants working at different steps of the agro-industrial chain. The following assumptions are made:

1. values are referred to one ha and to the year 2005,

2. the farm is a dairy farm of average size estimated at 100 ha situated in Pianura Padana using the practice of cultural rotation; 
3. the industrial plant for oil crushing plus chemical extraction has a working capacity of 50 thousand $t$.

Table 13: Products and market value for one ha of sunflower cultivation

\begin{tabular}{lccc}
\hline Product & Quantity (t) & Value Euro /t & Turnover \\
\hline Seeds & 2.4 & 265 & $636^{*}$ \\
Oil (crushing and chemical extraction) & 1.253 & 560 & 701,68 \\
Meal (1-2\% oil) & 1.147 & 120 & 135,600 \\
\hline Total & & & 837,280 \\
\hline
\end{tabular}

*Price with integrations determined with the inter-professional agreement

Table 14: Economic balance of biodiesel chain Euro /Ha

\begin{tabular}{|c|c|c|}
\hline Income from: & Euro $/ \mathrm{Ha}$ & $\%$ \\
\hline Biodiesel (final product) & 925.6 & 77.91 \\
\hline Glycerin (byproduct 1) & 142.4 & 11.99 \\
\hline Meal $1-2 \%$ oil (byproduct 2 ) & 120 & 10.10 \\
\hline Total income & 1188 & 100.00 \\
\hline \multicolumn{3}{|c|}{1 - Costs of phase 1: sunflower production (farming stage) } \\
\hline Technical input* & 141 & \\
\hline \multicolumn{3}{|l|}{ Of which seed for cultivation } \\
\hline Custom hire (machinery) & 140 & \\
\hline Non-machinery labor & 15 & \\
\hline Land charge / rent & 90 & \\
\hline Miscellanea & 14 & \\
\hline TOTAL FARMING COST & 400 & 100 \\
\hline \multicolumn{3}{|c|}{2 - Cost of phase 2: mechanical and chemical oil extraction (industrial stage 1) } \\
\hline Material (sunflower seed) & 346 & \\
\hline Processing & 72.58 & 80.00 \\
\hline Total extraction cost & 418.73 & 100.00 \\
\hline \multicolumn{3}{|c|}{3 - Cost of phase 3: trans-esterification (industrial stage 2) } \\
\hline Material, reagent, energy & 39,872 & 27.18 \\
\hline Labor $(\mathrm{L})$ & 21,36 & 14.56 \\
\hline Capital ( C ) & 52,688 & 35.92 \\
\hline Taxes $(\mathrm{T})$ & 14,24 & 9.71 \\
\hline Overhead (SG) & 18,512 & 12.62 \\
\hline Total trans-esterification process & 146,672 & 100.00 \\
\hline
\end{tabular}

Assuming to participate in an integrated agro-industrial chain managed as a cooperative organization; in this case the farmers will add the net income of the industrial chain. The total cost for industrial processing is 947 Euro/ha but because farmers are involved in the business, the cost for seed is not considered to avoid duplication. The net income obtained by selling the industrial products (biodiesel+glycerin) is $707.73 \mathrm{Euro} / \mathrm{ha}$ and the net biodiesel income is 347.5 Euro/ ha, that will be added to net farm income to obtain 3622.5 Euro/ha. 
Table 15: Balance of the integrated energy cogeneration farm based on one ha and two cows

\begin{tabular}{lcc}
\hline Product & Production per year & Value in Euro/ha \\
\hline A) Income & $2,5 \mathrm{t} /$ ha $\times 180$ Euro/t* & 450 \\
Sunflower seed & premium 1 & 45 \\
UE integration & premium 2 & 40 \\
Regional integration & $2 \times 10$ t $\times 320$ Euro /t & 6400 \\
Milk & 2 Calf Frison breed & 400 \\
Meat & 1.8 Mwh (price of GC $=10 \mathrm{c} / \mathrm{KW}$ ) & 180 \\
Electricity & & 7525 \\
Total farm income & & \\
\hline B) Costs & One ha with hired labor/machinery & 400 \\
Sunflower cultivation & Accounting data & 3450 \\
Dairy costs & Accounting data & 200 \\
Electricity cost & & 4050 \\
Total cost & & 3475 \\
Net farm income & &
\end{tabular}

This sunflower price is determined by the inter-professional

Agreement between producers and industry

Source: data elaborated by the author from different sources

The nominal value of the ha will be determined with the capitalization of the net farm income assuming a capitalization ratio equal to $5 \%$ to obtain a capital value equal to 65,500 Euro per ha; including the biodiesel income the value will increase to 72,450 Euro /ha.

Table 16:

\begin{tabular}{lcc}
\hline \multirow{2}{*}{ Voice } & \multicolumn{2}{c}{ Chain management } \\
\cline { 2 - 3 } & Independent & Cooperative \\
\cline { 2 - 3 } Farm income ( see table 11) & Value Euro/t & Value Euro/t \\
Farm cost & 7525 & 7525 \\
Net farm net income & 3475.00 & 3475.00 \\
& 4050.00 & 4050.00 \\
Industry income biodiesel+glycerol(1) & 1068.00 & \\
Industrial cost of which & & 1068.00 \\
a) seed & 450.00 & \\
b) processing & 72.58 & 72.58 \\
c) trans-esterification costs & 146.67 & 146.67 \\
Total industrial cost & 669.25 & 219.25 \\
Net industrial income & 398.75 & 848.75 \\
otal net income & & 4898.75 \\
\hline
\end{tabular}

(1) it is assumed the meal is given to farmers

Industrial net income 


\section{CONCLUSION}

With the integrated production system and the co-generative farm, a possibility is demonstrated of improving their economic, energetic and ecological balances; the farmers are playing a new role as producers and sellers of different form of energy (fuel, foods, heating, electricity). The results obtained are quite positive when compared with other arm activities and justify the higher investments and management skills required to manage this complex production system. These results are obtained in a quasi-competitive situation: productions are subsidized and fuels are de-fiscalized in accordance with the current law. Future improvements are expected by improving the scale dimension and coordination among the different chain stages. Future expectations are good: the demand for biofuel is high and farm won't have to worry if the biofuel policy will be in favor of farm productions. Finally, according to the Kyoto protocol, the ecological benefits procured by green energy will be priced in future and they could offer another market opportunity.

\section{REFERENCES}

Brunori, G., Rossi, A., Balducci, E., 2003. Valutazione della fattibilità economica ambientale e socio-territoriale dello sviluppo della filiera Biocarburanti in Toscana, in "BIOVIT: Biolubrificanti per l'Industria Toscana”, D.to di Agronomia e Gestione dell'Agrosistema, Sezione di Economia Agraria ed Ambientale.

Canadian Agricultural New Uses Council, 2004. Biodiesel and Other Chemicals from Vegetable Oils and Fats, Agriculture and Agri-Food Canada.

Ceddia, G., 2005. The Impact of Agro-Biotechnology on the Canola Seed Industry and Canola Productivity: Technological Lock in?) ICABR International Conference on Agricultural Biotechnology: Ten Years After.

Enguidanos, M., Soria, A., Kavalov, B., Jensen, P., 2002. Techno-Economic Analysis of Biodiesel Production in the EU: a Short Summary for Decision Makers, EU Commission Joint Research Center, Report EUR 20279 EN.

Griffin, J.M., Steele, H.B., 1986. Energy: Economics and Policy, $2^{\text {nd }}$ Edition.

Hill, J., Nelson, E., Tilman, D., Polasky, S., Tiffany, D., 2006. Environmental, economic, and energetic costs and benefits of biodiesel and ethanol biofuels, Proceedings of the National Academy of Sciences.

Klein, S., Rosemberg, N., 1986. An Overview of Innovation, In: Landau R., N. Rosemberg (eds), "The Positive Sum Strategy: Harnessing Technology for Economic Growth" National Academy Press, Washington D.C.

Morana, C., 2005. Energy Substitution in Italy: an Economic Evaluation, F. Angeli (ed)., Milano.

Outlaw, J., Collins, K.J., Duffield, J.A., 2005. Agriculture as a Producer and Consumer of Energy, CABI Publishing Co., Cambridge MA.

Phillips, P.W.B., Khachatourians, G.G., 2001. The Biotechnology Revolution in Global Agriculture: Invention, Innovation and the Investment in Canola Sector.

Pimentel, D., Patzek, T.W., 2005. Ethanol Production Using Corn, Switchingrass, and Wood; Biodiesel Production Using Soybean and Sunflowers, Natural Resources Research, 14: 65-76.

Rosa, F., 2006. Energie rinnovabili dal settore agricolo: Network Analysis In: a cura di F. Rosa, "Sentieri dell'innovazione nel territorio, dinamiche di sviluppo ed aggregazione - Il caso Italia-Romania", Forum, Udine.

Quaim, M., De Janvry, A., 2003. Genetically Modified Crops, Corporate Pricing Strategies and Farmers Adoption: the Case of Cotton BT in Argentina, American Journal of Agricultural Economics 85(4): 814-828.

Riva, G., et al, 2006. Agroenergie: filiere locali per la produzione di energia elettrica da girasole, Progetto PROBIO, Regione Marche. 
Shumaker, G., et al, 2003. A study on the feasibility of biodiesel production in Georgia. Center for Agribusiness and Economic Development, University of Georgia.

Sutton, J., 1998. Technology and Market Structure: Theory and History. MIT Press, Cambridge, Massachusetts.

Vannozzi, G.P, Nicli, M., 2006. Materie prime rinnovabili: le prospettive di utilizzo di colture oleaginose per filiere alimentary ed energetiche. In: a cura di F. Rosa, Sentieri dell'innovazione nel territorio, dinamiche di sviluppo ed aggregazione - Il caso Italia-Romania, Forum, Udine.

Van Thuijl, E., Deurwaarder, E.P., 2006. European Biofuel Policies in Retrospect, Energy Research Centre of the Netherlands, ECN-C-06-016, pp. 1-50.

Zhang, Y., Dubé, M.A, McLean, D.D., Kates, M., 2003. Biodiesel Production from Waste Cooking Oil: Economic Assessment and Sensitivity Analysis, Bioresource Technology 90: 229240.

\title{
LA GRANJA EN LA CUAL SE UTILIZAN LA ENERGÍA TERMAL Y LA ENERGÍA ELÉCTRICA COMBINADA
}

\author{
RESUMEN
}

La necesidad creciente de energía, cada vez mayor falta de combustibles fósiles y el cuidado creciente del medio ambiente, han incitado los creadores de la política en los EE.UU. y en Europa, de iniciar una búsqueda de las fuentes de energía alternativas, y el sector agricultor podría ofrecer una solución eficaz para este problema. El objeto de este trabajo es la investigación de las posibilidades de producción de biocombustible en las granjas y en las plantas industriales, como si fueran ellos el ejemplo de la "economía isleña" es decir, de ser exportadores de la energa neta, si el valor económico de la energía, biocombustibles y sus productos secundarios, supera el precio de las inversiones directas e indirectas en la producción de tal energía. El análisis está dedicado especialmente a los aspectos económicos, energéticos y ecológicos del acercamiento de la producción de energía doble, que completa el modelo isleño y que demuestra que es suficientemente sostenible para aguantar la competencia en el sentido económico y energético. Ese modelo se basa en la plantación de girasol que se utiliza para la producción de biodiesel, mientras que el producto secundario, es decir, la tortilla de girasol, se utilizaría en la producción de productos lácteos, el residuo se reciclaría en la producción de biogás para la producción de la corriente eléctrica y calor, y el compost final se utilizaría de fertilizante. Tal proyecto de una producción doble integral de energía en las granjas (IFECO), requiere analizar diferentes fases de la cadena agroindustrial y destinar fondos para la construcción de plantas energéticas y los gastos operativos; para el manejo de la cadena energética agroindustrial integral, se necesita la mano de obra calificada; por ello, la eficiencia de utilización del proyecto IFECO, dependerá de la habilidad de organizar y coordinar numerosas actividades en diferentes segmentos de la cadena. Las metas macroeconómicas, como empleo, valor añadido, importación de productos energéticos e inflación, justifican la intervención estatal pública en los programas orientados hacia defiscalización de la producción de biodiesel, como hacia la dotación de los cultivos energéticos, como soya, girasol, etc. Los resultados obtenidos en el proyecto IFECO, indican que la cantidad total de la energía producida en la cadena de producción de girasol, es significativamente mayor que la energía invertida, y el beneficio económico se refleja a través de un significante incremento de ingreso anual y del valor del terreno, a través de capitalización del ingreso neto de la granja permanente. $Y$ finalmente, el ahorro en el ciclo de calentamiento global sustituyendo el combustible fósil (reducción de 
la emisión de CO, VOC, PM10, SOx, NOx) es una valiosa contribución al mejoramiento de las condiciones ecológicas de la biosfera, lo que debe ser tomado en consideración como valor mercantil, si se aplica el Protocolo de Kyoto.

\title{
FERME OÙ LES ÉNERGIES THERMIQUE ET ÉLECTRIQUES SONT UTILISÉES CONJOINTEMENT
}

\author{
RÉSUMÉ
}

Le besoin de plus en plus grand d'énergie, la rareté de plus en plus grande de carburants fossiles et le souci de plus en plus marqué pour l'environnement ont incité les responsables aux Etats-Unis et en Europe à se mettre à la recherche de sources alternatives d'énergie ; le secteur agricole pourrait offrir une solution efficace à ce problème. Le but de ce travail est d'étudier la chaîne agro-industrielle pour produire du biocarburant dans les fermes et les centrales industrielles comme si elles étaient un exemple "d'économie des pays insulaires" c'est-à-dire comme si elles étaient des exportateurs d'énergie nette seulement dans la mesure où la valeur économique de l'énergie, du biocarburant et de ses coproduits excède le prix des investissements directs et indirects de la production de cette énergie. L'analyse est consacrée particulièrement aux aspects économiques, énergétiques et écologiques de la démarche de production d'énergie double qui complète le modèle insulaire et qui montre qu'il est suffisamment durable pour soutenir la concurrence au point de vue économique et énergétique. Ce modèle est basé sur la culture du tournesol utilisé dans la production du biodiesel tandis que le coproduit, la farine de tournesol, serait utilisée dans l'industrie laitière ; les déchets seraient recyclés dans la production de biogaz pour la production de courant électrique et de chaleur et le compost final serait utilisé pour la fertilisation. Un tel projet de production intégrale double d'énergie dans les fermes (IFECO) exige qu'on analyse les différentes phases de la chaîne agro-industrielle et que l'on réserve des investissements à la construction d'usine énergétiques et aux frais d'exploitation; une main d'œuvre plus qualifiée est nécessaire pour la gestion d'une chaîne agro-industrielle énergétique intégrale ; c'est pourquoi l'efficacité dans l'utilisation du projet IFEO dépendra de la compétence à organiser et coordonner les nombreuses activités dans différentes parties de la chaîne. Les buts macroéconomiques comme l'emploi, la valeur ajoutée, l'importation de produits énergétiques et l'inflation justifient une intervention de l'État dans les programmes orientés vers la défiscalisation de la production de biodiesel et des subventions aux cultures énergétiques comme le soja, le tournesol, etc. Les résultats obtenus dans le projet IFECO démontrent que la quantité d'énergie totale produite dans la chaîne de production du tournesol est significativement plus grande que l'énergie investie et le profit économique se reflète dans une augmentation importante du revenu annuel et de la valeur du sol par la capitalisation du revenu permanent de la ferme. Enfin, l'économie dans le cycle global par le remplacement du carburant fossile (réduction des émissions de CO, VOC, $\mathrm{PM} 10, \mathrm{SO}_{\mathrm{x}}, \mathrm{NO}_{\mathrm{x}}$ ) est une contribution précieuse à l'amélioration des conditions écologiques de la biosphère, ce qui doit être pris en considération comme valeur marchande si on applique le Protocole de Kyoto. 